logos_i_ethos_2019_2_(50), s. 159-178

DOI: http://dx.doi.org/10.15633/lie.3483

Piotr Stanisław Mazur

https://orcid.org/0000-0002-6399-8133

Akademia Ignatianum

\title{
Chrześcijańska filozofia człowieka w Polsce wobec wyzwań XX i XXI wieku'
}

Chrześcijańska filozofia człowieka nigdy nie stanowiła i nie stanowi intelektualnego monolitu. W wieku XX w Polsce stanęła ona przed poważnymi wyzwaniami intelektualnymi, które okazały kluczowe dla jej rozwoju. Dramatyczne zwroty o charakterze społecznym, politycznym czy kulturowo-cywilizacyjnym sprawiły, że stawały przed nią coraz to nowe zadania. Odpowiedzią była dr hab. Piotr Stanisław Mazur, prof. nadzw. filozof, publicysta, poeta, kierownik Katedry Filozofii Bytu, Człowieka i Społeczeństwa w Akademii Ignatianum w Krakowie. Opublikował m.in.: Intelekt człowieka (Lublin 2004); W kręu pytań o człowieka (Lublin 2008); Prowidencja ludzka jako podstawa roztropnego formowania zasad zycia osobowego i społecznego człowieka (Lublin 2009); O polską kulturę humanistyczną (Lublin 2011); Zarys podstaw filozofii człowieka. Antropologiczne zastosowanie metody separacji (Kraków 2016); Metafizyka istnienia człowieka (Kraków 2018).

1 Pomimo toczących się dyskusji związanych z określeniem tego, co jest „filozofią polską” oraz czy istnieje „filozofia chrześcijańska” i co przez nią rozumieć, oba te określenie funkcjonują w literaturze filozoficznej. W pierwszym przypadku można przyjąć, że jest to literatura filozoficzna wpisująca się w obszar kultury polskiej, wyznaczonej przede wszystkim przez język publikacji i przynależność do polskiego środowiska naukowego. Znacznie większych trudności dostarcza tu rozumienie „filozofii chrześcijańskiej”. Zob. P. S. Mazur, Filozofia chrześcijańska dziś, w: Filozofia i chrześcijaństwo, Warszawa 2007, s. 185-198. W sensie najogólniejszym można za nią uznać „[...] taki typ filozofii, w której do głosu dochodzi afirmatywne podejście do dziedzictwa myślowego, intelektualnego chrześcijaństwa" (K. Stachewicz, O filozofii chrześcijańskiej. Kilka uwag z perspektywy historycznej i futurologicznej, „Logos i Ethos” 2013 nr 2 (35), s. 230-231). W prowadzonych tu rozważaniach będzie ona natomiast rozumiana jako filozofia tworzona przez myślicieli inspirujących się chrześcijaństwem lub identyfikujących się z nim (wymiar podmiotowy), bądź jakoś związana z chrześcijaństwem z uwagi na sposób (przedmiot, cel lub pod pewnym względem także metodę - postawę zajmowaną przez filozofa w poznaniu rzeczywistości) filozofowania (wymiar przedmiotowy). 
modyfikacja starych lub pojawianie się nowych odmian personalizmu. Nigdy jednak nie utraciła jednak swojego zasadniczego rdzenia, jakim jest afirmacja osobowego statusu człowieka. Także w pierwszych dekadach XXI wieku powinna szukać nowych sposobów odkrywania i afirmacji prawdy o osobowym statusie człowieka.

\section{Specyfika chrześcijańskiej filozofii człowieka}

Chrześcijańska filozofia człowieka odwołuje się do różnych tradycji i nurtów filozofowania. Niezależnie od dzielących je różnic wspólnym ich mianownikiem jest personalizm, akcentujący osobowy status człowieka. Nie każdy personalizm ma charakter chrześcijański, ale trudno wyobrazić sobie, aby chrześcijańska filozofia była a- czy anty-personalistyczna ${ }^{2}$.

Personalizm chrześcijański (kolektywnie pojmowany) ma charakter filozoficzny, ale jest głęboko zakorzeniony w porządku wiary, w którym wyjątkowość człowieka podkreśla fakt, że sam Bóg jest osobą (a właściwie wspólnotą osób). Jezus Chrystus zaś jako odwieczne Słowo, realizując zawarte przez Boga przymierze z człowiekiem, wcielił się, przyjmując ludzką naturę z duszą i ciałem, aby odkupić człowieka z niewoli grzechu. Poprzez dobrowolne przyjęcie śmierci na krzyżu doskonałe wypełnił wolę Boga Ojca, stając się dla człowieka osobowym wzorem. „[...] Wolny od grzechu, urzeczywistnił w sobie, i to ponadobficie, pierwotnie zamierzoną przez Boga doskonałość natury ludzkiej”’3. Zatem człowiek,

2 Ignacy Dec odróżnia: 1) personalizmy horyzontalne, 2) personalizmy teistyczne (teocentryczne) - pozatomistyczne (moralno-społeczny, fenomenologiczno-aksjologiczny, egzystencjalistyczno-dialogiczny, ewolucyjno-kosmiczny), i 3) personalizm klasyczny (tomistyczny). Pierwszy rodzaj personalizmów (L. Feuerbacha, K. Marksa, F. Engelsa, F. Nietzschego, S. Freuda, B. Russela, C. Lévi-Straussa, J.-P. Sartre’a, w Polsce - T. Kotarbińskiego) ma charakter antropocentryczny (humanizm), ale najczęściej jest zarazem naturalistyczny i ateistyczny. Zob. I. Dec, Personalizm $w$ filozofii: (próba systematyzacji), w: Personalizm polski, red. ks. M. Rusecki, Lublin 2008, s. 301-313 (Biblioteka Teologii Fundamentalnej, 3). Dlatego jest on trudny do pogodzenia z chrześcijaństwem. Jednocześnie nie każdy naturalizm musi być ateistyczny i antypersonalistyczny, co pokazuje koncepcja naturalizmu teistycznego (M. Heller, J. Życiński). Pozostałe personalizmy w różnym stopniu są do pogodzenia z chrześcijaństwem lub wprost wyrastają z inspiracji chrześcijańskich.

3 J. Salij, Jezus Chrystus, w: Katolicyzm A-Z, red. Z. Pawlak, Poznań 1999, s. 187. 
jego upadła natura jako przedmiot Bożego działania znajdują się w centrum kerygmatu, bez którego także sam kerygmat traci sens. W chrześcijaństwie człowiek, i to człowiek jako indywidualny podmiot, niezależnie od swoich działań i pozycji społecznej, zasługuje więc na to, aby być przedmiotem działania Boga, przez co uwyraźnia się jego szczególna godność.

Wojciech Chudy stwierdza, że do własności personalizmu chrześcijańskiego należy: „Po pierwsze [...], że osoba jako osoba stanowi najdoskonalszy typ bytu. Po drugie [...], że Bóg jest Osobą. Po trzecie [...], że człowiek-osoba w wymiarze bytowym transcenduje zarówno relację gatunek - jednostka, jak i relacje społeczeństwo - jednostka. Po czwarte [...] formułuje normę moralną mówiącą, że człowieka-osoby nigdy nie wolno traktować przedmiotowo, instrumentalnie, jako środka działania, a tylko i zawsze jako cel"4.

Zatem przy wszystkich różnicach filozoficznych, jakie dzielą chrześcijańskie personalizmy, pozostaje pewien religijny i teologiczny depozyt, do którego się odwołują. Personalizmy te za Chudym można podzielić na: metafizyczny, etyczny i liberalistyczny ${ }^{5}$. Pierwszy z nich sięga do Boecjańskiej definicji osoby, akcentując jednostkowość istnienia i rozumną naturę oraz podmiotowość i godność. Są to jednak cechy, jak podkreśla Chudy, ujmujące osobę niejako z zewnątrz, gdzie „opisu i wyjaśnienia dokonuje się w oparciu o teorię metafizyczną, o uprzednio

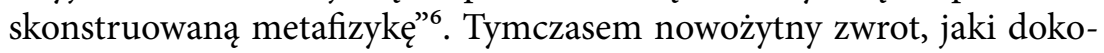
nał się za sprawą filozofii Kartezjusza, doprowadził do wyeksponowania roli subiektywności, świadomości, nieokreśloności natury i wolności, wyrażając przez to dynamizm i aktowość osoby.

Personalizm liberalistyczny wysuwa na plan pierwszy w życiu osobowym człowieka kwestię wolności. Odrzucając przekonanie o stałości natury ludzkiej, uznaje się w nim wolność za podstawy czynnik samookreślenia się człowieka. Człowiek nie tyle jest osobą, ile się nią staje

4 W. Chudy, Pedagogia wolności. Elementy etyki pedagogicznej, Lublin 2009, s. 39.

5 Zob. W. Chudy, Pedagogia wolności. Elementy etyki pedagogicznej, dz. cyt., s. 27-36.

6 W. Chudy, Pedagogia wolności. Elementy etyki pedagogicznej, dz. cyt., s. 28 
w swoim rozwoju i relacjach z innymi osobami i społecznością. Osobowy status człowieka nie jest czymś ściśle dookreślonym i najczęściej nie wpisuje się w jakiś całościowy, zwarty system filozoficzny.

Personalizm etyczny stanowi pewną modyfikację personalizmu metafizycznego lub liberalistycznego. Pierwsza polega na dopełnieniu ujęcia metafizycznego aspektem subiektywno-refleksyjnym, czego rezultatem jest określenie osoby od strony metafizycznej i od strony świadomościowej. W drugim natomiast przypadku następuje przesunięcie akcentu $\mathrm{z}$ wolności na prawdę, w niej zaś akcent pada na osobową godność. Obie te modyfikacje można dostrzec zdaniem Chudego, w głównej pracy Karola Wojtyły, jaką jest Osoba i czyn. Do metafizycznego ujęcia osoby włącza on ujęcie od strony świadomościowej, natomiast zasadniczy akt osobowy, za jaki uznaje samostanowienie, dokonuje się za sprawą woli, ale pokierowanej obiektywną prawdą o sobie, która czyni go osobą sobie daną i zadaną ${ }^{7}$.

\section{Wyzwanie pierwsze - poszukiwanie właściwego modelu życia społecznego}

W rezultacie zmian, jakie zaszły w wyniku I wojny światowej oraz upadku mocarstw zaborczych w 1918 roku, Polska odzyskała niepodległość. Zasadniczym wyzwaniem, przed jakim stanęła w tym okresie chrześcijańska filozofia, było określenie swojego stanowiska w sporze na temat kształtu życia społecznego. Problematyka społeczna nabierała coraz większego znaczenia od połowy XIX wieku, co znalazło także wyraz w nauczaniu Kościoła katolickiego. Papież Leon XIII uznał za konieczne podjęcie dyskusji z rosnącym w siłę socjalizmem, ogłaszając w 1891 roku encyklikę Rerum novarum. Jednakże rewolucja bolszewicka, jaka dokonała się w Rosji w 1917 roku i powstanie pierwszego na świecie państwa komunistycznego, pokazywały jak niebezpieczne są kiełkujące w ówczesnym czasie ideologie.

7 Zob. W. Chudy, Pedagogia wolności. Elementy etyki pedagogicznej, dz. cyt., s. 35. 
W sporze o kształt życia społecznego ujawniały się nie tylko różnice polityczne i społeczne, lecz także stojące u ich podstaw różnice antropologiczne, określające relacje między człowiekiem a społecznością. Myśliciele chrześcijańscy okresu międzywojennego skupiali się przede wszystkim na wypracowaniu własnego stanowiska w kwestiach społecznych ${ }^{8}$. Nie przez przypadek personalizm tego okresu określa się mianem społecznego.

W okresie międzywojennym ścierały się ze sobą odziedziczony jeszcze po humanizmie i reformacji indywidualizm $z$ prądami pozytywistycznymi i ewolucjonistycznymi, do których odwoływały się kolektywizmy społeczne w postaci komunizmu i nazizmu. Mając to na względzie, Jacek Woroniecki stwierdza, że indywidualizm kiełkujący w odrodzeniu i reformacji z sfery religii przeszedł także do pozostałych dziedzin życia ludzkiego, dochodząc do szczytu podczas rewolucji francuskiej. Zwrot w przeciwnym kierunku dokonał się w wieku XIX za sprawą socjalizmu, który w działaniu sięgał po metody rewolucyjne. Efektem tych przemian był totalitaryzm ${ }^{9}$.

O ile więc indywidualizm przeciwstawiał człowieka jako jednostkę rozumną (indywiduum) społeczności, przejawiając się w partykularyzmie i fideizmie, o tyle kolektywizm żądał uznania społeczności naczelnych państwa (totalizm etatystyczny) lub narodu (totalizm nacjonalistyczny) za cel ostateczny człowieka. Woroniecki podkreśla, że państwo i naród są konieczne dla człowieka, ale są środkiem jego rozwoju osobowego, a nie jego celem ${ }^{10}$. Człowiek ma bowiem swój własny cel ostateczny, transcendujący społeczność, któremu podporządkowane są ostatecznie wszystkie cele społeczne.

W podobnym tonie wypowiada się Karol Górski, twierdząc za Jakiem Maritainem, że indywidualizm wyrósł z humanizmu antropocentrycznego, a współcześnie opiera się na hedonizmie, natomiast kolektywizm

8 W okresie międzywojennym działała cała plejada chrześcijańskich myślicieli społecznych, akcentujących potrzebę personalistycznego urządzenia życia społecznego, m.in.: J. Woroniecki, A. Szymański, F. Koneczny, H. Romanowski, J. Piwowarczyk, J. Stepa, K. Górski.

9 Zob. J. Woroniecki, Katolicka etyka wychowawcza, t. 1, Lublin 2013, s. 86.

10 Por. J. Woroniecki, Katolicka etyka wychowawcza, dz. cyt., s. 260. 
traktuje człowieka jako ewolut materii, podporządkowując go społeczności. Podobnie jak Woroniecki dochodzi do wniosku, że właściwy rozwój człowieka jako bytu spotencjalizowanego dokonuje się w społeczności - rodzinie, narodzie i państwie, których jednak charakter musi być personalistyczny ${ }^{11}$.

Antropologia chrześcijańska, sprzeciwiając się indywidualizmowi, nie mogła również zaakceptować kolektywizmu. Dlatego za alternatywę uznano personalizm. Charakter tego personalizmu został zaś określony przez to, co działo się w Kościele w drugiej połowie XIX wieku i na początku wieku XX. Myśl chrześcijańska znajdowała w sytuacji odrodzenia scholastyki, do którego impuls dał Leon XIII w 1879 roku encykliką Aeterni Patris, nawołując wprost „,ite ad Thomam”, a Pius X w roku 1914 sformułował słynne 24 tezy filozofii Tomaszowej. Odwołanie do myśli św. Tomasza zostało związane z edycją oryginalnych prac myślicieli średniowiecznych i ich krytycznym opracowaniem. Temu odrodzeniu neoscholastyki towarzyszyło dążenie do przeciwstawienia się pozytywistycznemu scjentyzmowi negującemu wiarę, metafizykę czy etykę. Wyrazem przekonania o niesprzeczności porządku wiary i rozumu było również powstawanie uniwersytetów katolickich.

Kształt personalizmu okresu międzywojennego ze zrozumiałych powodów określał więc tomizm. Miał on charakter metafizyczny o nachyleniu społecznym, co doskonale widać właśnie pracach Woronieckiego. Człowiek jako substancja natury rozumnej jest bytem osobowym, ale zarazem spotencjalizowanym. Aktualizacja dokonuje się w procesie wychowania do dobra. Jest więc pedagogiką silnie sprzęgniętą z etyką indywidualną i społeczną.

\section{Wyzwanie drugie - totalitaryzm kolektywistyczny}

Dla rozwoju chrześcijańskiej filozofii człowieka w Polsce ważną cezurą była II wojna światowa. Represje wojenne ze strony niemieckiej i sowieckiej były ukierunkowane na zniszczenie narodu poprzez zagładę

11 Zob. K. Górski, Państwo chrześcijańskie średniowiecza, Warszawa 1938, s. 22-28. 
zwłaszcza inteligencji i duchowieństwa, prowadząc do aktów ludobójstwa. W jej rezultacie państwo polskie znalazło się pod całkowitą dominacją Związku Sowieckiego, w którym panowała totalitarna ideologia komunistyczna. Narzędziem dalszej represji stały się marionetkowe władze, narzucające społeczeństwu marksizm podobnie jak w całej Europie Wschodniej. Represje te dotknęły zwłaszcza świat nauki i kultury. Dążono do całkowitego wyrugowania z życia uniwersyteckiego niezależnej od marksizmu filozofii, zlikwidowano wydziały teologiczne na uniwersytetach w Krakowie, gdzie jeszcze w 1931 roku rektorem był ks. Konstanty Michalski, oraz w Warszawie. W czasie wojny nauka polska poniosła ogromne straty intelektualne. Znaczna część elity intelektualnej została wymordowana przez Sowietów w Katyniu oraz przez Niemców w ramach akcji $\mathrm{AB}$. Zatem potencjał tych, którzy przeżyli wojnę i okupację, był szczególnie cenny i powinien być należycie wykorzystany. Tymczasem komunistyczne władze, dążąc do intelektualnego zapanowania nad społeczeństwem, zwolniły z pracy wielu wybitnych filozofów, m.in.: Romana Ingardena, Izydorę Dąmbską, Władysława Tatarkiewicza. „Otóż te wydarzenia, które miały miejsce w Polsce po dojściu do władzy marksistów, przyniosły skutki podobne do tych, jakie wyniknęły w związku z procesami, które już wcześniej wystąpiły w Europie Zachodniej w okresie pooświeceniowym. Mówiło się m.in. o «zmierzchu realizmu tomistycznego», a równocześnie próbowano to rozumieć jako odwrót od chrześcijaństwa jako źródła filozofowania"12.

Narzędzia politycznego działania były intelektualnie prymitywne, choć jednocześnie dość skuteczne. Zagrożenie było więc realne. Jego charakter, na tle doświadczeń chrześcijańskiego personalizmu, szybko zdiagnozowano: marksizm jako ideologia opierał się na fałszywej wizji człowieka, który w pisanej kilka dziesięcioleci później encyklice Centesimus annus Jan Paweł II nazwał „błędem antropologicznym”. W punkcie 13 tej encykliki dokonał zaś dogłębnej analizy tego błędu: 
[...] podstawowy błąd socjalizmu ma charakter antropologiczny. Rozpatruje on bowiem pojedynczego człowieka jako zwykły element i cząstkę organizmu społecznego, tak że dobro jednostki zostaje całkowicie podporządkowane działaniu mechanizmu ekonomiczno-społecznego; z drugiej strony utrzymuje on, że dobro jednostki można urzeczywistnić, nie uwzględniając jej samodzielnego wyboru i niezależnie od przyjęcia przez nią w sposób indywidualny i wyłączny odpowiedzialności za dobro czy zło. Człowiek zostaje w ten sposób utożsamiony z pewnym zespołem relacji społecznych, a jednocześnie zanika pojęcie osoby jako samodzielnego podmiotu decyzji moralnych, który podejmując je, tworzy porządek społeczny ${ }^{13}$.

U źródeł błędnej koncepcji natury osoby ludzkiej leży zdaniem papieża ateizm. Negacja Boga „prowadzi do takiego ukształtowania porządku społecznego, w którym ignorowana jest godność i odpowiedzialność osoby" ${ }^{14}$. Rezultatem błędu antropologicznego jest natomiast podważenie godności człowieka, deformacja prawa oraz ograniczenie wolności i własności prywatnej, uniemożliwiając tworzenie autentycznej ludzkiej wspólnoty.

Bezpośredni atak na tomizm sprawił, że chrześcijańska filozofia człowieka tego okresu, podobnie jak w okresie przedwojennym odwołała się do personalizmu tomistycznego, wprowadzając jednak do swojego dyskursu nowe elementy interpretacyjne zaczerpnięte $\mathrm{z}$ tomizmu egzystencjalnego. Kontekst społeczno-polityczny w Polsce sprzyjał teoretycznemu pogłębianiu samego tomizmu, w którym metafizyczny realizm łączono z badaniami historyczno-filozoficznymi (S. Swieżawski, M. Gogacz) oraz gruntowną podbudową logiczno-metodologiczną (S Kamiński, M. A. Krąpiec, A. B. Stępień), zaś w niektórych wersjach - z naukami przyrodniczymi (K. Kłósak, S. Mazierski). W zakresie filozofii człowieka, obok problematyki osoby, podejmowano kwestie struktury bytowej, a więc złożenia z duszy i ciała (K. Kłósak, M. A. Krąpiec, K. Wojtyła) i rozwijano tradycyjną psychologię filozoficzną, jako naukę o duszy i jej

13 Jan Paweł II, Centesimus annus, https://opoka.org.pl/biblioteka/W/WP/jan_pawel_ii/encykliki/centesimus_1.html (25.05.2019).

14 Jan Paweł II, Centesimus annus, dz. cyt. 
władzach (J. Pastuszka), badano problem ludzkiego poznania (M. A. Krąpiec, A. B. Stępień).

Jednocześnie z tej racji, że część wyrzuconych z państwowych uczelni profesorów znajdowała pracę w uczelniach katolickich, zaczęly do tych środowisk przenikać także inne nurty, jak za sprawą Ingardena fenomenologia na KUL (A. B. Stępień). Z kolei izolacja uczelni katolickich i kościelnych w PRL-u wymuszała kontakty z filozofią zachodnią, gdzie w obrębie chrześcijaństwa zaczęły stopniowo przeważać inne niż tomistyczne poglądy, co ujawniło się podczas soboru watykańskiego II.

\section{Wyzwanie trzecie - odejście od tomizmu w obrębie nauczania Kościoła}

Kolejne wyzwanie, przed jakim stanęła chrześcijańska filozofia człowieka w Polsce, wyszło z wnętrza samego Kościoła i związane było z soborem watykańskim II, który odbywał się w latach 1962-1965. Podczas soboru doszło do znaczącej zmiany w podejściu Kościoła do tomizmu, który dotychczas traktowany był preferencyjnie jako filozoficzna podstawa wiary ${ }^{15}$. Za dopełnienie tej zmiany w aspekcie antropologicznym można uznać ogłoszenie soborowej Deklaracji o wolności religijnej.

Filozoficzna przemiana, jaka zaszła podczas soboru, nie była nagłym zwrotem, lecz wyrastała dominującego na Zachodzie Europy klimatu

15 Przekonanie, że spór o filozofię (tomizm) stanowil jeden z głównych problemów soboru, wyrażał jeden z jego uczestników, Stefan Swieżawski. Na ten temat zob. P. Gutowski, Stefan Swieżawski wobec Soboru Watykańskiego II, „Ethos” 25 (2012) nr 4, s. 250. Sam Swieżawski, broniąc mądrościowego charakteru filozofii, sprzeciwiał się ideologizowaniu myśli Akwinaty. Podczas soboru zarysowały się trzy zasadnicze stanowiska względem myśli św. Tomasza: 1) uznanie całości jego doktryny za prawdziwą i wzorcową dla chrześcijaństwa (podkreślenie prawdziwości twierdzeń); 2) uznanie, że Tomasz był wzorem teologa, który potrafił wykorzystać filozofię Arystotelesa do wyrażenia prawd chrześcijańskich (podkreślenie znaczenia metody podejścia do problemów filozoficznych); 3) uznanie, że doktryna Tomasza nie jest bezwzględnie prawdziwa (nie wszystko, co twierdził, da się współcześnie utrzymać), ale nie można zignorować jego filozoficznych odkryć (podkreślenie walorów intelektualnych myśli św. Tomasza). Zob. P. Gutowski, Stefan Swieżawski wobec Soboru Watykańskiego II, dz. cyt., s. 247-248. Swieżawski opowiadał się za ostatnim podejściem, głosząc potrzebę filozofii: metafizycznej, realistycznej, racjonalistycznej, mądrościowej, egzystencjalnej. 
intelektualnego, od którego polska filozofia była zasadniczo odcięta. Dlatego na gruncie polskim, gdzie niepodzielnie dominował tomizm, miała tak silny rezonans. Przemianę tę klarownie ujął szwajcarski teolog i filozof Romano Amerio: „Znamiennym faktem teologii posoborowej jest odrzucenie tomizmu właśnie jako filozofii, czyli jako zbioru tez, i uczynienie zeń wyłącznie pewnej metodologii dostosowanej do ducha czasów" ${ }^{16}$. Z kolei w wyjaśnieniu, na czym polegała ta metodologia, Amerio przywołuje koncepcję flamandzkiego dominikanina Edwarda Schillebeeckx’a, który podkreślał, że Tomasz jakoby dokonał swoistej chrześcijańskiej sekularyzacji. W swojej filozofii miał bowiem, odwrotnie niż Bonawentura, wychodzić od poznania świata, a kończyć na poznaniu Boga. I to właśnie metoda dialogu ze światem, a nie same tezy, byłaby najcenniejszą spuścizną po Akwinacie. W przeciwieństwie do tez, które wymagają akceptacji i aplikacji, wartością metody tomistycznej byłoby otwarcie poznania na wymiar horyzontalny. Zdaniem Ameria takie pojmowanie myśli tomistycznej niejako uwalniało teologię od tomizmu jako doktryny, co z kolei znalazło wyraz w dokumentach. „Ataki przypuszczone na tomizm podczas Soboru Watykańskiego II nie pozostały bez wpływu na treść wydawanych wówczas dokumentów. W dekrecie Optatam totius w sprawie formacji kapłańskiej znalazł się zapis, że należy wpajać alumnom solidną i spójną wizję człowieka, świata i Boga «W oparciu o nieprzemijającą spuściznę filozoficzną, jednak bez wymieniania tomizmu»"17. A zatem uznano, że w uprawianiu teologii tomizm może być zastąpiony innymi filozofiami, a wraz z tym, że wpisany weń personalizm metafizyczny - innymi personalizmami.

Z kolei soborowa Deklaracja o wolności religijnej Dignitatis humanae z 1965 głosi m.in., że prawdy nie można nikomu narzucić siłą. Dlatego osobie ludzkiej przysługuje prawo do wolności religijnej. „Tego zaś rodzaju wolność polega na tym, że wszyscy ludzie powinni być wolni od przymusu ze strony czy to poszczególnych ludzi, czy to zbiorowisk s. 619 .

16 R. Amerio, Iota Unum. Analiza zmian w Kościele katolickim w XX wieku, Komorów 2009,

17 R. Amerio, Iota Unum. Analiza zmian w Kościele katolickim w XX wieku, dz. cyt., s. 619-620. 
społecznych i jakiejkolwiek władzy ludzkiej, tak aby w sprawach religijnych nikogo nie przymuszano do działania wbrew jego sumieniu ani nie przeszkadzano mu w działaniu według swego sumienia prywatnym i publicznym, indywidualnym lub w łączności z innymi, byle w godziwym zakresie. [...] Prawo do wolności religijnej jest [...] zakorzenione w samej godności osoby ludzkiej, którą to godność poznajemy przez objawione słowo Boże i samym rozumem" ${ }^{18}$.

Sobór uznał wolność sumienia, zgodnie z którym każdy wierzący $\mathrm{z}$ racji swojej osobowej godności ma prawo sam poznać prawdę i według niej żyć, co było rewolucyjne. Podejście to nie mogło nie wpłynąć na filozofię, bo skoro każdy wierzący ma prawo do szukania prawdy, to tym bardziej wolność w jej poszukiwaniu powinien mieć filozof czy teolog. Stąd wniosek, że nie powinno się narzucać nawet prawdziwej czy słusznej doktryny filozoficznej i tym samym antropologii. Jednocześnie w deklaracji tej szczególny akcent padł na godność człowieka. Położenie nacisku na osobową godność człowieka, którą w filozofii podkreślał zwłaszcza nurt kantowski, i jego akty (poznawcze - sumienie czy decyzyjne - wolność), zamiast na substancjalność i rozumną naturę, było wyrazem przejścia w spojrzeniu na osobę ludzką od aspektu metafizycznego do aspektu etycznego.

W chrześcijańskiej filozofii człowieka w Polsce za wyraz przejścia od tomistycznej antropologii do nowego sposobu mówienia o człowieku można uznać Osobę i czyn Karola Wojtyły ${ }^{19}$ oraz Schytek chrześcijaństwa tomistycznego Józefa Tischnera ${ }^{20}$. Pierwsze $\mathrm{z}$ tych dzieł nie odrzuca tomizmu, lecz dopełnia go poznaniem fenomenologicznym, odnoszącym się do strony świadomościowo-przeżyciowej ludzkiego podmiotu,

18 W deklaracji tej można dopatrzeć się echa Powszechnej Deklaracji Praw Człowieka przyjętej i proklamowanej rezolucją Zgromadzenia Ogólnego ONZ w dniu 10 grudnia 1948 roku, której artykuł 18 głosi, że każdy człowiek ma prawo do wolności myśli, sumienia i religii, https://www. google.com/url? $\mathrm{sa}=\mathrm{t} \& \mathrm{rct}=\mathrm{j} \& \mathrm{q}=\& \mathrm{esrc}=\mathrm{s} \&$ source $=$ web\&cd=1\&ved=2ahUKEwj0qKnbw5reAhVR h6YKHRBpCoYQFjAAegQICRAC\&url=http\%3A\%2F\%2Fwww.unesco.pl\%2Ffileadmin\%2Fuser upload\%2Fpdf\%2FPowszechna_Deklaracja_Praw_Czlowieka.pdf\&usg=AOvVaw38Vh3qwvtZvZ NaApDNHkk2 (22.10.2018).

19 K. Wojtyła, Osoba i czyn, Kraków 1969.

20 J. Tischner, Schyłek chrześcijaństwa tomistycznego, „Znak” 22 (1970) nr 187 (1), s. 1-20. 
drugie - korzystając z fenomenologii - uznaje tomizm za przeżytek, i sprzeciwia się roszczeniu tomizmu do wyłączności w obrębie katolicyzmu. W ten sposób uwyraźniły się dwa nowe chrześcijańskie personalizmy. Zgodnie z podziałem Chudego pierwszy miał charakter etyczny, drugi zaś w dojrzałej formie będzie przejawiał cechy personalizmu liberalistycznego. Można więc uznać, że pojawienie się na gruncie polskiej filozofii chrześcijańskiej personalizmów w wersji etycznej i liberalistycznej było odpowiedzią na wyzwanie, jakim była wyraźna zmiana stosunku Kościoła katolickiego do tomizmu, która dokonała się podczas soboru watykańskiego II. Pierwszy chciał tomizm ocalić, dopełniając go nowszymi koncepcjami poznania człowieka, drugi szukał nowego sposobu odkrycia czy wyrazu prawdy o człowieku jako osobie.

Ponieważ w obrębie filozofii chrześcijańskiej przełomu lat 6o. i 70. $\mathrm{XX}$ wieku tomizm wciąż dominował, personalizmy te musiały niejako wywalczyć sobie przestrzeń życiową, co budziło opór i krytykę. Warto przypomnieć choćby o dyskusji, jaką wywołało opublikowanie Osoby i czynu ${ }^{21}$. Można postawić tezę, że gdyby Wojtyła nie był kardynałem i dyskurs odbywał się w swobodniejszych intelektualnie warunkach zewnętrznych, to krytyka jego dzieła byłaby o wiele poważniejsza. W 1974 roku ukazała się monografia Mieczysława A. Krąpca, Ja-człowiek ${ }^{22}$, którą można też uznać za szczytowe osiągnięcie personalizmu tomistycznego i głos w sporze z personalizmem etycznym i liberalistycznym. Ścieranie się tych trzech personalizmów trwało, aż do końca naukowej aktywności ich głównych przedstawicieli. W różnych aspektach spór personalizmu etycznego z metafizycznym po wyborze kard. Wojtyły na papieża, toczył się głównie między Tadeuszem Styczniem i Andrzejem Szostkiem oraz Mieczysławem A. Krąpcem ${ }^{23}$, zaś personalizmu liberalistycznego

21 Przebieg dyskusji nad Osobą i czynem, która miała miejsce 16 grudnia 1970 roku w Lublinie (KUL), zawierają „Analecta Cracoviensia” 5-6 (1973-1974), s. 49-297.

${ }^{22}$ M. A. Krąpiec, Ja-człowiek, Lublin 1974.

23 Więcej na temat tego sporu: E. Kaczyński, Etyka powinności czy etyka decyzji? Spór T. Stycznia z A. Krąpcem. Próba zrozumienia, „Studia Theologica Varsaviensia” 29 (1991) nr 2, s. 61-77; W. Chudy, Spór w szkole lubelskiej o podstawy i punkt wyjścia etyki, „Roczniki Filozoficzne” 45 (1997) nr 1, s. $200-210$. 
i tomistycznego - przede wszystkim między Józefem Tischnerem a Mieczysławem A. Krąpcem ${ }^{24}$. Spory te uwikłane były w całościowe koncepcje filozofii prezentowane przez poszczególnych myślicieli.

Z dzisiejszej perspektywy wypada podkreślić, że 1) przedstawiciele odmiennych nurtów filozofii chrześcijańskiej, a więc i personalizmów mają świadomość dzielących ich różnic, doceniając jednak wzajemnie swoje znaczenie i osiągnięcia; 2) pomimo poważnych różnic filozoficznych przedstawiciele tych nurtów naukowo współpracują ze sobą; 3) widoczne jest dążenie do jakiegoś zintegrowania tych personalizmów, przynajmniej co do osiągniętych rezultatów, czemu sprzyja wspólny religijno-teologiczny depozyt personalistyczny.

\section{Wyzwanie czwarte - naturalistyczny antypersonalizm i transhumanizm}

Wraz z upadkiem komunizmu po 1989 roku i pełnym otwarciem na współczesny dyskurs filozofia chrześcijańska stanęła przed kolejnym wyzwaniem. Jest nim zderzenie z różnymi odmianami antypersonalizmu. Podważa się nie tylko osobowy status człowieka, ale i cały ufundowany na zdrowym rozsądku obraz bytu ludzkiego, uznając podmiotowość człowieka za całkowicie fikcyjny twór ${ }^{25}$. Oznacza to, że doświadczenia jaźni, tożsamości, świadomości, samoświadomości i samowiedzy nie uznaje się za nośnik wiarygodnej wiedzy na temat człowieka. Nie ma już miejsca na wyróżnioną pozycję człowieka w kosmosie, na ludzką wolność i decyzyjność czy na wolną od biologiczno-społecznych uwarunkowań miłość. W dyskursie dominuje naturalizm, który znajduje oparcie w naukach szczegółowych. Jednocześnie w kulturach świata

24 Więcej na temat tego sporu: Z. Dymarski, Debata księdza Józefa Tischnera ze szkołą lubelską, „Logos i Ethos” $1998 \mathrm{nr}$ 1, 235-245; A. Wilczek, W poszukiwaniu prawdy o człowieku. Spór księdza Józefa Tischnera z tomizmem, „Czasopismo Filozoficzne” 2009 nr 4/5, s. 52-72; B. Listkowska, Podmiot czy przedmiot? Józefa Tischnera i Mieczysława A. Krąpca spór o koncepcję człowieka, „Filo-Sofija” 15 (2015) nr 31, s. 229-246.

25 Por. P. S. Mazur, Zarys podstaw filozofii człowieka. Antropologiczne zastosowanie separacji metafizycznej, Kraków 2016, s. 9-58. 
zachodniego postępuje degradacja społecznej pozycji człowieka, z wieloma zagrożeniami dla jego naturalnych uprawnień i presją antypersonalistycznego układania relacji społecznych. Zachodzące w samej filozofii przemiany celnie ujmuje Vittorio Possenti:

Aporie pochodzące ze spotkania scjentystycznego pozytywizmu z irracjonalnym decyzjonistycznym egzystencjalizmem są dziś nie mniej niepokojące niż dawniej, a nawet poważniejsze $\mathrm{z}$ racji rosnących możliwości dysonowania człowiekiem, które daje nauka. Występuje on często w szatach Neutralnego, gdzie podmiot (lub to, co z niego pozostało) zostaje zredukowany do wiecznego biegu przyrody, czyli physis. [...] Pamiętajmy o szeroko rozpowszechnionej postawie empirystycznej, której przedstawiciele, idąc śladami Hume’a, odmawiają znaczenia terminowi "godność ludzka", zastępując go anonimowym odniesieniem do pojęcia życia. Jest to najwyższy stopień antypersonalizmu, w którym idea osoby nie może powrócicić ${ }^{26}$.

W chwili obecnej za najważniejsze wyzwanie dla personalizmu należy uznać coraz większą dominację paradygmatu naturalistycznego w samej filozofii, który podważa wszystko to, na czym tradycyjnie wspiera się personalizm, a więc istnienie tak czy inaczej uzasadnianego pierwiastka duchowego w człowieku, odczytywanego przez pryzmat różnych aktów osobowych: poznawczych (np. świadomość) i wolitywnych (np. samostanowienie), wskazujących na jego bytowy status wyrażający się w godności.

Odrzucając metafizykę, podważa się podstawy personalizmu metafizycznego, głoszącego, że osoba jest substancją natury rozumnej. Odrzucając porządek normatywny, podważa się nie tylko etykę, ale i etyczny personalizm, podkreślający, iż osoba $\mathrm{z}$ uwagi na godność bycia celem, stanowi najwyższą wartość. W końcu także na tle uznania różnych determinizmów: biologicznych, psychicznych, społecznych czy kognitywistycznych, neguje się ludzką wolność, na której zogniskowany jest personalizm liberalistyczny. Tym samym znosi się wszystkie

26 V. Possenti, Osoba nową zasadą, tłum. J. Merecki, Lublin 2017, s. 26-27. 
tradycyjne uzasadnienia, ale i intelektualne narzędzia, przy pomocy których dotychczas uzasadniało się, że człowiek jest bytem osobowym.

Z kolei ugruntowany na naturalizmie i dopełniający go transhumanizm roztacza alternatywę stosunkowo łatwego przejścia człowieka do doskonalszego sposobu bytowania, sprawiając, że personalistyczna koncepcja człowieka, z jego spotencjalizowaną naturą, która wymaga przede wszystkim aktualizacji od wewnątrz, wydaje się mało atrakcyjna. Postulat obrony antropologicznego status quo, w perspektywie potencjalnego udoskonalenia tego, co jest, $\mathrm{w}$ dyskursie społecznym spycha personalizm jako całość, a więc niezależnie od tego, jaką przyjmuje postać, do wyraźnej defensywy, sprawiając wrażenie, że jest on wrogi człowiekowi.

Ponieważ chrześcijańska filozofia człowieka nie może nie być personalistyczna, zatem powinna w nim szukać odpowiedzi na te współczesne wyzwania. Symptomy pierwszej odpowiedzi już się pojawiają. Nie przybrały one dotychczas charakteru stanowiska teoretycznego, ale są widoczne niejako przy okazji sposobu podejmowania innych problemów filozoficznych, jak filogeneza czy relacja mózg-umysł. W podejściu tym uznaje się zaczerpnięte $\mathrm{z}$ nauk przyrodniczych rozstrzygnięcia dotyczące człowieka (najczęściej obarczone naturalizmem) za wiążące filozoficznie, sprowadzając tym samym antropologię do roli metanauki ${ }^{27}$. Prowadzi to do akceptacji poglądu, że w porządku natury nie ma wystarczającej racji przemawiającej za uznaniem wyjątkowego statusu człowieka. Wykorzystanie odróżnienia poznania potocznego i naukowego pozwala przy tym na rezygnację ze znajdywania lub w ogóle poszukiwania naukowych przesłanek na rzecz personalizmu i ograniczenie się

27 Kwestia stosunku filozofii do rezultatów poznawczych uzyskiwanych w naukach przyrodniczych cały czas jest dyskutowana przez filozofów chrześcijańskich, co uwidocznia się choćby w tradycyjnym już sporze środowiska lubelskiego ze środowiskiem krakowskim (przynajmniej jeśli chodzi o stanowiska skrajne). Przedmiotem sporu nie jest to, czy ignorować wiedzę uzyskiwaną w naukach szczegółowych, lecz czy winna ona stanowić punkt wyjścia filozofii (autonomia poznania), zakładając, że uznaje się ją za formę poznania naukowego. O ile na terenie filozofii przyrody dominuje przekonanie, że autonomia ta nie jest dzisiaj możliwa, o tyle w zakresie filozofii człowieka problem ten nie jest tak jednoznaczny. 
do referowania tradycyjnych stanowisk w filozofii. Takie podejście może być klarowne metodologicznie, ale jest wyniszczające antropologicznie. Nawet jeśli nie wiąże się ono z całkowitym odrzuceniem personalizmu, który stanowi fundament chrześcijańskiej antropologii, to wyprowadza problem osoby poza teren poznania naukowego (filozoficznego). Jest to forma intelektualnego poddania personalizmu dominującemu dyskursowi naturalistycznemu. Taki fideistyczny personalizm jest jakoś zrozumiały psychologicznie, gdyż pozwala pokonać intelektualny rozziew pomiędzy naukowym naturalizmem a wiarą. Jednakże jest on mało użyteczny teologicznie, bo na poziomie racjonalnego dyskursu nie wspiera religijnych przekonań dotyczących człowieka (transcendencja nad przyrodą), nie dostarczając racjonalnych (filozoficznych) argumentów na rzecz osobowego statusu człowieka. To zaś oznacza zrzeczenie się prawa do udziału w filozoficznym dyskursie na jego temat i zgodę na postępującą depersonalizację i dehumanizację życia społecznego i kultury.

Chrześcijańską odpowiedzią na antypersonalistyczny naturalizm może i powinien być personalizm. Powstaje jednak pytanie: jaki? Czy ma to być jakiś nowy personalizm, czy odmiana jednego $\mathrm{z}$ dotychczasowych personalizmów okaże się dopiero post factum w świetle całościowego przebiegu dyskursu. Być może odpowiedź ta ograniczy się do krytykowanego tu personalizmu fideistycznego. Brak odpowiedzi na postawione wyżej pytanie nie stoi jednak na przeszkodzie, by wysuwać wnioski czy zgłaszać w tej kwestii postulaty.

$\mathrm{W}$ przeszłości łącznikiem wszystkich personalizmów chrześcijańskich był personalizm religijny czy teologiczny ${ }^{28}$. W chwili obecnej natomiast panuje niepisana zgoda, że poszczególne odmiany chrześcijańskiego personalizmu, przy całej swojej odmienności i wzajemnej krytyce, zwłaszcza w początkowej fazie ich formowania, uzupełniają się. Należałoby zatem dążyć do ukształtowania personalizmu integralnego, który

${ }^{28}$ Odróżnienie personalizmu religijnego (teologicznego) od personalizmu fideistycznego ma sens, jeśli się pamięta, że personalizm religijny jest wyrazem chrześcijańskiej doktryny i moralności, podczas gdy personalizm fideistyczny wynika z przekonania, że w porządku natury nie ma podstaw dla uznania osobowego statusu człowieka. Pierwszy ma charakter pozytywny, drugi negatywny. 
łączyłby odmiany metafizyczną, etyczną, liberalistyczną i fideistyczną, spójnie argumentując na rzecz osobowego statusu człowieka ${ }^{29}$. Chodzi o to, by wciąż na nowo stawiać problem osoby w centrum naukowego dyskursu i czynić to w sposób nieredukcyjny.

\section{Zakończenie}

Pomimo wielości personalizmów różnej proweniencji i ich przynależności do różnych tradycji filozoficznych to właśnie prawdę o człowieku jako osobie ukierunkowanej ostatecznie na osobowego Boga można uznać za integralny element chrześcijańskiej antropologii. Dramatyczne zmiany kulturowe, społeczne i religijne, jakie dokonywały się w wieku $\mathrm{XX}$, wpłynęly w istotny sposób na kształt tego personalizmu. Jako całość, pomimo zmienności akcentów i przesuwania się od personalizmu metafizycznego ku etycznemu i liberalistycznemu, chrześcijańska antropologia była $\mathrm{w}$ stanie adekwatnie odpowiedzieć na nowe uwarunkowania i płynące z nich wyzwania. Także w pierwszych dekadach wieku XXI, wobec coraz silniejszego naporu naturalizmu i utrwalenia się naturalistycznego paradygmatu w filozofii i kulturze oraz nośnego hasła transhumanizmu potrzeba takiej odpowiedzi. Personalizm fideistyczny nie stanowi wystarczającej odpowiedzi na to wyzwanie, należy jej poszukiwać w personalizmie integralnym, łączącym wszystkie istotne elementy wiedzy o człowieku jako osobie, które zostały wypracowane zwłaszcza w ostatnim stuleciu w obrębie chrześcijańskiej antropologii.

29 W pewnym sensie takie próby podejmował choćby Chudy, podkreślając trzy aspekty osoby: metafizyczny, aksjologiczny i teologiczny. Zob. W. Chudy, Prawda człowieka i prawda o człowieku, w: Człowiek - wartości - sens. Studia z psychologii egzystencji. Logoteoria i nooteoria. Logoterapia i nooterapia, Lublin 1996, s. 129-148. 


\section{Bibliografia}

„Analecta Cracoviensia” 5-6 (1973-1974), s. 49-297.

Amerio R., Iota Unum. Analiza zmian w Kościele katolickim w XX wieku, Komorów 2009.

Chudy W., Pedagogia wolności. Elementy etyki pedagogicznej, red. M. Szudra, Lublin 2009.

Chudy W., Filozofia chrześcijańska - rozum i wiara, „Ethos” 20 (2007) nr 3-4 (79-80), s. $45-66$.

Chudy W., Prawda człowieka i prawda o człowieku, w: Człowiek - wartości - sens. Studia z psychologii egzystencji. Logoteoria i nooteoria. Logoterapia i nooterapia, Lublin 1996, s. $129-148$.

Chudy W., Spór w szkole lubelskiej o podstawy i punkt wyjścia etyki, „Roczniki Filozoficzne” 45 (1997) nr 1, s. 200-210.

Dec I., Personalizm w filozofii (próba systematyzacji), w: Personalizm polski, red. ks. M. Rusecki, Lublin 2008 (Biblioteka Teologii Fundamentalnej, 3), s. 301-313.

Dymarski Z., Debata księdza Józefa Tischnera ze szkołą lubelską, „Logos i Ethos” 1998 nr 1, 235-245.

Górski K., Państwo chrześcijańskie średniowiecza, Warszawa 1938.

Gutowski P., Stefan Swieżawski wobec Soboru Watykańskiego II, „Ethos” 25 (2012) nr 4, s. 243-261

Jan Paweł II, Pamięć i tożsamość, Kraków 2005.

Kaczyński E., Etyka powinności czy etyka decyzji? Spór T. Stycznia z A. Krąpcem. Próba zrozumienia, „Studia Theologica Varsaviensia” 29 (1991) nr 2, s. 61-77.

Krąpiec M. A., Porzucić świat absurdów, Lublin 2002.

Listkowska B., Podmiot czy przedmiot? Józefa Tischnera i Mieczystawa A. Krąpca spór o koncepcję człowieka, „Filo-Sofija” 15 (2015) nr 31, s. 229-246.

Mazur P. S., Zarys podstaw filozofii człowieka. Antropologiczne zastosowanie separacji metafizycznej, Kraków 2016.

Possenti V., Osoba nowa zasada, tłum. J. Merecki, Lublin 2017.

Powszechna Deklaracja Praw Człowieka, https://www.google.com/url?sa=t\&rct=j\&q $=\&$ esrc $=$ s\&source $=$ web \&cd $=1 \& v e d=2 \mathrm{ahUKEwj0qKnbw5}$ reAhVRh6YKHRBpCoY QFjAAegQICRAC\&url=http\%3A\%2F\%2Fwww.unesco.pl\%2Ffileadmin\%2Fuser_ upload\%2Fpdf\%2FPowszechna_Deklaracja_Praw_Czlowieka.pdf\&usg=AOvVaw3 8Vh3qwvtZvZNaApDNHkk2, (22.10.2018).

Salij J., Jezus Chrystus, w: Katolicyzm A-Z, red. Z. Pawlak, Poznań 1999, s. 187. 
Stachewicz K., O filozofii chrześcijańskiej. Kilka uwag z perspektywy historycznej i futurologicznej, „Logos i Ethos” 2013 nr 2 (35), s. 219-234.

Tischner J., Schyłek chrześcijaństwa tomistycznego, „Znak” 22 (1970) nr 187 (1), s. 1-20.

Wilczek A., W poszukiwaniu prawdy o człowieku. Spór księdza Józefa Tischnera z tomizmem, „Czasopismo Filozoficzne” 2009 nr 4/5, s. 52-72.

Wojtyła K., Osoba i czyn, Kraków 1969.

Woroniecki J., Katolicka etyka wychowawcza, Lublin 2013.

\section{Abstrakt}

\section{Chrześcijańska filozofia człowieka w Polsce wobec wyzwań XX i XXI wieku}

Według autora artykułu antropologia chrześcijańska charakteryzuje się afirmatywnym podejściem do chrześcijaństwa i personalizmu w rozumieniu człowieka. W ciągu ostatniego stulecia w Polsce stanęła ona przed czterema kluczowymi wyzwaniami dla jej rozwoju, którymi były: 1) poszukiwanie właściwego modelu życia społecznego związanego z odrzuceniem indywidualizmu i kolektywizmu; 2) zderzenie z totalitaryzmem kolektywistycznym (komunizmem), który narzucał błędną koncepcję człowieka; 3) rezygnacja Kościoła w jego nauczaniu z dominacji tomistycznego modelu rozumienia świata i człowieka; 4) ustanowienie naturalistycznego i transhumanistycznego modelu człowieka w kulturze przełomu XX i XXI wieku. Antropologia chrześcijańska odpowiedziała na pierwsze trzy wezwania specyficznym typem personalizmu: społecznym - w pierwszym przypadku; metafizycznym - w drugim, liberalistycznym i etycznym - w trzecim. Zdaniem autora artykułu obecnie musi ona szukać personalistycznej odpowiedzi na czwarte wyzwanie. Antropologii chrześcijańskiej zagraża fideistyczny personalizm wynikający z przyjęcia naturalistycznego obrazu człowieka pochodzącego z nauk szczegółowych i rezygnacja z prób filozoficznego uzasadnienia jego osobowego statusu.

\section{Słowa kluczowe}

filozofia chrześcijańska, filozofia polska, filozofia człowieka 


\section{Abstract \\ Christian Philosophy of Man in Poland in the Face of the Challenges of the 20th and 21st Centuries}

According to the author of the article, Christian anthropology is characterized by an affirmative approach to Christianity and personalism in the understanding of man. During the last century in Poland it faced four key challenges for its development which were: 1) searching for a proper model of social life connected with the rejection of individualism and collectivism; 2) the clash with collectivist totalitarianism (communism) which imposes an erroneous concept on man; 3 ) resignation of the Church in her teaching from the domination of the Thomistic model of understanding the world and man; 4) establishment of a naturalistic and transhumanistic model of man in the culture of the turn of the 20th and 21st centuries. Christian anthropology responded to the first three calls with a specific type of personalism: social - in the first case, metaphysical - in the second, liberalist and ethical - in the third. At present time, it must seek a personalistic response to the fourth challenge, while the author believes that Christian anthropology is threatened by fideistic personalism resulting from the acceptance of the naturalistic image of man coming from detailed sciences and the abandonment of attempts to philosophically justify his personal status.

\section{Keywords}

Christian philosophy, Polish philosophy, philosophical anthropology 